\title{
Zinc Finger Transcription Factors as Molecular Targets for Nitric Oxide-mediated Immunosuppression: Inhibition of IL-2 Gene Expression in Murine Lymphocytes
}

\author{
Denise Berendji, ${ }^{1}$ Victoria Kolb-Bachofen, ${ }^{1}$ Peter F. Zipfel, ${ }^{2}$ \\ Christine Skerka, ${ }^{2}$ Carsten Carlberg, ${ }^{3}$ and Klaus-D. Kröncke \\ ${ }^{1}$ Research Group Immunobiology and the ${ }^{3}$ Institute of Physiological \\ Chemistry I, MED-Heinrich-Heine University of Düsseldorf, \\ Düsseldorf, Germany \\ ${ }^{2}$ Research Group of Biomolecular Medicine, Bernhard Nocht Institute \\ for Tropical Medicine, Hamburg, Germany
}

Accepted September 20, 1999.

\begin{abstract}
Background: Nitric oxide (NO) has frequently been shown to display immunosuppressive activities. We describe here a molecular mechanism contributing to this effect.

Materials and Methods: Murine $\mathrm{T}$ cell lymphoma EL4-6.1 cells were activated with the physiological stimulus interleukin (IL) $-1 \beta$ to express IL- 2 mRNA in the presence or absence of subtoxic concentrations of the physiological spontaneous NO donor $S$-nitrosocysteine (SNOC). Subsequently, semiquantitative RT-PCR and gel shift assays with nuclear extracts were performed to analyze the effects of NO on IL-2 mRNA expression and on the activity of the dominant regulating transcription factors Spl, EGR-1, and NFATc.

Results: NO inhibits IL- $1 \beta$-induced IL- 2 mRNA expression in EL4-6.1 cells. The suppressive activity of NO was concentration dependent and found to be completely reversible. Importantly, NO at the concentrations used induced neither apoptosis nor necrosis. Dominant regu-
\end{abstract}

lation of IL-2 gene expression is known to reside in the zinc finger transcription factors Spl or EGR-1 and in the non-zinc finger protein NFAT. NO abrogates the DNA binding activities of recombinant Spl and EGR-1. More importantly, gel shift assays also showed a lack of DNA binding of native Spl derived from NOtreated nuclear extracts and that from NO-treated viable lymphocytes. This effect is selective, as the DNA binding activity of recombinant NFATc was not affected by NO.

Conclusion: Inactivation of zinc finger transcription factors by NO appears to be a molecular mechanism in the immunosuppressive activity of NO in mammals, thus contributing to NO-mediated inhibition of IL-2 gene expression after physiological stimuli. The exact understanding of the molecular mechanism leading to NOmediated, fully reversible suppression of immune reactions may lead to use of this naturally occuring tool as an aid in inflammatory diseases.

\section{Introduction}

Since the discovery of nitric oxide (NO) as a biologically active molecule, NO has been found

Address correspondence and reprint requests to: Dr. Klaus-D. Kröncke, Research Group Immunobiology 14.80, MED-Heinrich-Heine University Düsseldorf, P.O. Box 1010 07, D-40001 Düsseldorf, Germany. Phone: 49-211-8119546; FAX: 49-211-81-19532; E-mail: kroencke@uniduesseldorf.de to play an important role as a signal molecule in many parts of the organism and as a cytotoxic or regulatory effector molecule of the innate immune response. The signal molecule NO is synthesized in a regulated, short-pulsing manner by constitutively expressed NO synthases. By contrast, inducible NO synthase is expressed after cell activation by cytokines and/or bacterial products such as lipopolysaccharide and then 
produces NO for long periods of time $(1,2)$. This high-output synthesis of NO participates in inflammatory and autoimmune-mediated tissue destruction (3). Besides mediating direct cytotoxicity, a regulatory and immunosuppressive role for NO at higher concentrations has been reported (4-6), as has the observation that macrophage-derived NO suppresses mixed lymphocyte reactions (7-10). These findings are in agreement with the observation that in a variety of diseases in which high-output NO synthesis is known to occur, concomitant immunosuppression occurs (11).

Transcriptional activation of the interleukin-2 (IL-2) gene and IL-2 secretion are essential steps for $\mathrm{T}$ cell proliferation and differentiation. Recently it has been shown that exogenously added NO inhibits IL-2 protein secretion in T lymphocytes (12-16) as well as the IL-2 promoter activity of lymphocytes in a reporter gene assay (14). In lymphocytes, IL-2 gene expression is regulated through a transcriptional enhancer region to which binding of both ubiquitous (NF$\kappa \mathrm{B}, \mathrm{AP}-1)$ and lymphocyte-specific (Oct-2, NFAT-1, TCF) transactivating factors has been described (17). In addition, the murine IL-2 promoter contains a zinc finger protein binding region (ZIP), which serves as a binding site for two zinc finger proteins, the constitutively expressed transcription factor Spl and the inducible early growth response protein EGR-1, both of which contain three well-characterized $\mathrm{Cys}_{2} \mathrm{His}_{2}$ zinc fingers (18). Zinc finger proteins are members of a large class of DNA binding proteins acting as transcription factors in modulating gene expression (19). In the human IL-2 promoter, the ZIP site serves as an activator for IL-2 gene expression, and its combination with the NFAT binding site is required for maximal IL-2 promoter activity $(20,21)$.

We have previously shown that NO inhibits the DNA binding activity of the zinc finger transcription factor LAC9 in yeast nuclear extracts (22) and that of nuclear receptors (23), and that exogenously added NO results in cytoplasmic and, more importantly, nuclear zinc release in mammalian cells (24). Here we investigate whether mammalian zinc finger proteins such as Spl and EGR-1 represent a molecular target for NO-mediated effects in cellular gene expression leading to immunosuppressive effects.

\section{Materials and Methods}

Materials

$\mathrm{H}_{2} \mathrm{O}_{2}$ was purchased from Merck (Darmstadt, Germany), L-cysteine- $\mathrm{HCl}$, phenylmethylsulfonyl fluoride (PMSF) and Hoechst 33342 were from Sigma (Deisenhofen, Germany), recombinant human IL-1 $\beta$ was from PBH (Hannover, Germany), and recombinant human Spl and $\mathrm{Spl}$ consensus oligonucleotide were from Promega (Heidelberg, Germany). Antibodies specific for Spl and EGR-1 were purchased from Santa Cruz Biotechnology (Santa Cruz, CA), DNA polymerase I, poly-deoxy-inosinic-deoxy-cytidylic acid (poly $[\mathrm{d}(\mathrm{I}-\mathrm{C})]$ ), and leupeptin was from Boehringer Mannheim (Mannheim, Germany). Expression of the recombinant proteins EGR-1 and NFATc was performed in the baculovirus system as described previously $(20,21)$. EGR-1 and NFAT concensus oligonucleotides were synthesized by BioSource (Ratingen, Germany). $S$-nitrosocysteine (SNOC) was synthesized as described previously (25). PAPA/NO ((Z)- 1 - [ $N$-(3-ammoniopropyl) - $N$-(n-propyl) amino]diazen-1-ium-1,2-diolate) was kindly provided by Olaf Grapenthin (Düsseldorf, Germany). Denitrosylated SNOC (SNOC $-\mathrm{NO}$ ) was obtained by incubating a $100 \mathrm{mM}$ stock solution of SNOC for $48 \mathrm{hr}$ at $37^{\circ} \mathrm{C}$.

\section{Cell Culture and Viability Tests}

EL4-6.1 mouse lymphoma cells were cultured in RPMI 1640, supplemented with $6 \times 10^{4} \mathrm{U} /$ liter penicillin, $60 \mathrm{mg} /$ liter streptomycin, $1 \mathrm{mM}$ sodium pyruvate, $2 \mathrm{mM}$ glutamine, $10 \mathrm{ml} /$ liter nonessential amino acids $(100 \times), 10 \mathrm{mM}$ HEPES (all from Life Technologies, Eggenstein, Germany), and $10 \%$ heat-inactivated fetal calf serum (FCS) (PAA Laboratories, Linz, Austria). After treatment with different concentrations of SNOC or $\mathrm{H}_{2} \mathrm{O}_{2}$, cellular necrosis was determined by trypan blue exclusion under a light microscope. Apoptosis was quantitated after cells were stained with Hoechst $33342(15 \mu \mathrm{M})$ and subsequent quantification of cells with condensed chromatin or fragmented nuclei was determined under a fluorescence microscope (Zeiss Axioplan, Zeiss Oberkochem, Germany) using the Zeiss filter set Nr. 02 (excitation $320-375 \mathrm{~nm} /$ emission LP $420 \mathrm{~nm}$ ). At least $10^{2}$ cells were counted per individual probe and experiments were performed at least in triplicate. 
Semiquantitative $R T-P C R$

EL4-6.1 cells $\left(1 \times 10^{5} /\right.$ well $)$ were placed in 12 well plates and incubated with $1000 \mathrm{U} / \mathrm{ml} \mathrm{IL}-1 \beta$ in the presence or absence of various concentrations of SNOC or $\mathrm{H}_{2} \mathrm{O}_{2}$ for $3 \mathrm{hr}$ in RPMI 1640 containing $2.5 \%$ FCS. Cells of three individual wells were pooled and total cellular RNA was isolated by the acid guanidinium thiocyanatephenol-chloroform extraction method (26). RNA (1 $\mu \mathrm{g}$ each) was used for cDNA synthesis (27). Reverse transcription (RT) was carried out at $42^{\circ} \mathrm{C}$ for $1 \mathrm{hr}$ using oligo(dT) primers. Polymerase chain reaction (PCR) was performed with this cDNA using the following primers:

IL-2.1: ATGTACAGCATGCAGCTCGCATC;

IL-2.2: GGCTTGTTGAGATGATGCTTTGACA (28);

GAPDH.1: ACAGTCCATGCCATCACTGC; GAPDH.2: AAGAAGGTGGTGAAGCAGGC.

The PCR profile for IL-2 was 34 cycles at $94^{\circ} \mathrm{C}$ for $30 \mathrm{sec}, 58^{\circ} \mathrm{C}$ for $30 \mathrm{sec}$, and $72^{\circ} \mathrm{C}$ for $30 \mathrm{sec}$, while GAPDH amplification was performed at $94^{\circ} \mathrm{C}$ for $30 \mathrm{sec}, 58^{\circ} \mathrm{C}$ for $30 \mathrm{sec}$, and $72^{\circ} \mathrm{C}$ for 30 sec for 22 cycles. PCR with fully induced cells and dilution series were performed to ensure that amplification conditions were in the linear phase only. An aliquot of each sample was electrophoresed on $2 \%$ agarose gels. Bands were visualized by ethidiumbromide staining. The IL2/GAPDH-ratio was obtained by densitometric analysis of visualized amplification product bands.

\section{Isolation of Nuclear Proteins}

EL4-6.1 cells $\left(5 \times 10^{6}\right)$ were harvested by centrifugation, washed twice with phosphate-buffered saline (PBS), and resuspended in $500 \mu \mathrm{l}$ of hypotonic homogenisation buffer $(15 \mathrm{mM}$ TrisHCl, 1 mM EDTA, 2 mM DTT, 10\% glycerol, 0.5 $\mathrm{mM}$ PMSF, $1 \mu \mathrm{M}$ leupeptin, $\mathrm{pH}$ 7.5). All subsequent steps were performed at $4^{\circ} \mathrm{C}$. After swelling for 5 min on ice, the cells were lysed by $2 \times$ 10 strokes of a glass Dounce homogenizer and the samples were centrifuged for $10 \mathrm{~min}$ at $5000 \times \mathrm{g}$. The supernatant fractions were discarded, and the nuclear pellets were washed twice with homogenization buffer, resuspended in $50 \mu$ l hypertonic extraction buffer $(20 \mathrm{mM}$ HEPES, $600 \mathrm{mM} \mathrm{NaCl}, 1.5 \mathrm{mM} \mathrm{MgCl}, 0.2 \mathrm{mM}$ EDTA, $20 \%$ glycerol, pH 7.9), and vortexed. After $1 \mathrm{hr}$ on ice, suspensions were centrifuged for $30 \mathrm{~min}$ at $24,000 \times \mathrm{g}$. The supernatant containing the nuclear proteins was harvested and stored at $-80^{\circ} \mathrm{C}$. Protein concentrations were determined by the method of Lowry et al. (29).

\section{Electrophoretic Mobility Shift Assay}

Specific gel shift probes were generated by radiolabeling double-stranded specific oligonucleotides with a fill-in reaction using $\left[\alpha^{32} \mathrm{P}\right] \mathrm{dCTP}$ and the Klenow fragment of DNA polymerase I. For each gel shift reaction, $2 \mu \mathrm{g}$ of nuclear extract from EL-4 6.1 cells or $25 \mathrm{ng}$ of recombinant $\mathrm{Spl}$ protein was preincubated for $10 \mathrm{~min}$ at room temperature in a total volume of $20 \mu \mathrm{l}$ binding buffer (10 mM Tris, $0.1 \mu \mathrm{g} / \mu \mathrm{l}$ poly (dI-C), $5 \%$ glycerol, $\mathrm{pH}$ 7.5). According to the volume of the nuclear extracts, salt concentrations were kept constant by addition of extraction buffer. Response elements were:

\section{Spl: ATTCGATCGGGGCGGGGCGAGC}

NFAT: CTAGAAAGAGGAAAATTTGT.

Approximately $1 \mathrm{ng}$ of radiolabeled probe $(25.000 \mathrm{cpm})$ was added and the incubation was continued for $30 \mathrm{~min}$. Protein-DNA complexes were resolved on $5 \%$ nondenaturating polyacrylamide gels at room temperature in $0.5 \times$ TBE (45 mM Tris, $45 \mathrm{mM}$ boric acid, $1 \mathrm{mM}$ EDTA, pH 8.3). Gels were dried and exposed to a Fuji MP2040S imager screen for $2 \mathrm{hr}$.

\section{Results}

Inhibition of IL-1 $\beta$-Dependent IL-2 mRNA Expression by $N O$

The murine lymphoma cell line EL4-6.1 expresses IL-2 following activation by IL- $1 \beta(30)$. We investigated the effect of NO on the IL-1 $\beta$ driven IL-2 mRNA expression in these cells and compared the effects obtained with those using $\mathrm{H}_{2} \mathrm{O}_{2}$ in the same system. As a source for NO, we used the spontaneous NO donor $S$-nitrosocysteine (SNOC).

To rule out the possibility that altered gene expression was due to onset of necrosis or apoptosis, the critical concentrations of both SNOC and $\mathrm{H}_{2} \mathrm{O}_{2}$ were first determined. Lymphocytes were screened 6 or $24 \mathrm{hr}$ after addition of NO or $\mathrm{H}_{2} \mathrm{O}_{2}$, respectively, using fluorescence microscopy and the DNA stain Hoechst 33342 . Apoptosis was clearly identified by chromatin condensation and/or fragmentation of cell nuclei. Concentrations of up to $1 \mathrm{mM}$ of SNOC and up to $0.5 \mathrm{mM}$ of $\mathrm{H}_{2} \mathrm{O}_{2}$ did not significantly induce apoptosis in EL4-6.1 cells within $6 \mathrm{hr}$ and only 


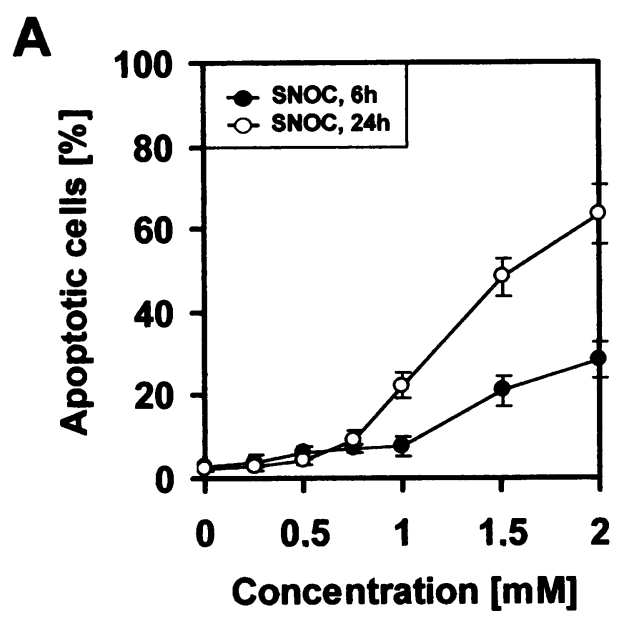

Fig. 1. Increasing concentrations of SNOC or $\mathrm{H}_{2} \mathrm{O}_{2}$ induce apoptosis in lymphocytes. EL4-6.1 cells were incubated for $3 \mathrm{hr}$ with increasing concentrations of SNOC (A) or of $\mathrm{H}_{2} \mathrm{O}_{2}$ (B). Cells were then washed and incubated in fresh medium. After additional 3- or $2 \mathrm{l}$-hr culture, apoptosis was quantitated by counting cells with condensed chromatin or

marginally within $24 \mathrm{hr}$ (Fig. 1). However, higher concentrations of SNOC as well as $\mathrm{H}_{2} \mathrm{O}_{2}$ did induce apoptosis in a time- and concentration-dependent manner. In addition, aliquots of the same cultures were tested for necrosis by trypan blue exclusion. The amount of trypan blue-positive cells never exceeded $5 \%$ at any of the SNOC or $\mathrm{H}_{2} \mathrm{O}_{2}$ concentrations or time points investigated. Denitrosylated SNOC $\left(\mathrm{SNOC}_{-\mathrm{NO}}\right)$ was used as a control and did not interfere with cell viability even at the highest concentration of $2 \mathrm{mM}(2.1 \pm 0.8 \%$ of the cells at the start of culture, $3.2 \pm 1.1 \%$ after $6 \mathrm{hr}$ and $3.5 \pm 0.9 \%$ after $24 \mathrm{~h} ; n=3$ ).

After activating EL4-6.1 cells with 1000 U/ml IL- $1 \beta$, IL- 2 mRNA expression could be detected by semiquantitative RT-PCR as early as after $2 \mathrm{hr}$, with maximal induction observed after $4 \mathrm{hr}$ (not shown). To examine the effects of NO on IL- $1 \beta$-dependent IL- 2 mRNA expression, EL4-6.1 cells were incubated with IL-1 $\beta$ in the absence or presence of various concentrations of SNOC for $3 \mathrm{hr}$. Semiquantitative RT-PCR revealed that NO donor treatment resulted in a concentration-dependent reduction in IL-2 mRNA expression (Fig. 2). IL-2-specific mRNA expression at the subtoxic SNOC concentration of $1 \mathrm{mM}$ was reduced by $86.2 \pm 6.9 \%(n=5)$. Expression of the housekeeping gene GAPDH was not affected by up to $1 \mathrm{mM}$ of SNOC, but declined at $2 \mathrm{mM}$ of SNOC, an additional indication of onset of apoptosis.

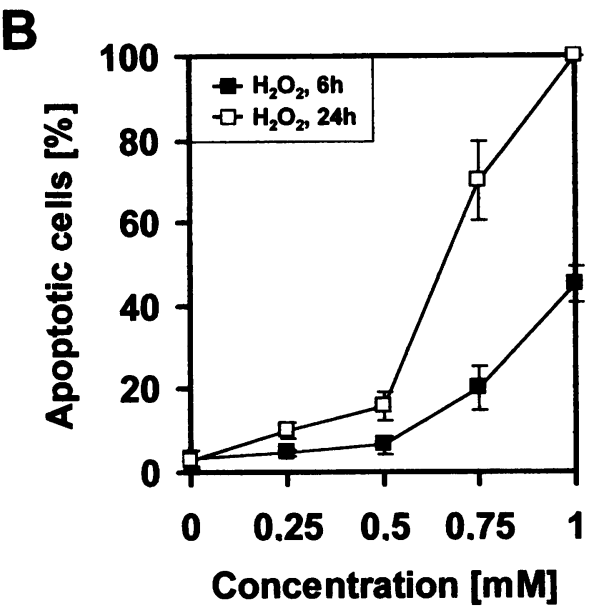

with fragmented nuclei after staining with Hoechst 33342. Concentrations of up to $1 \mathrm{mM}$ of SNOC or $0.5 \mathrm{mM}$ of $\mathrm{H}_{2} \mathrm{O}_{2}$ did not induce apoptosis. Experiments were performed in triplicate, with at least $10^{2}$ cells/well. Values are mean \pm SD of three independent experiments.

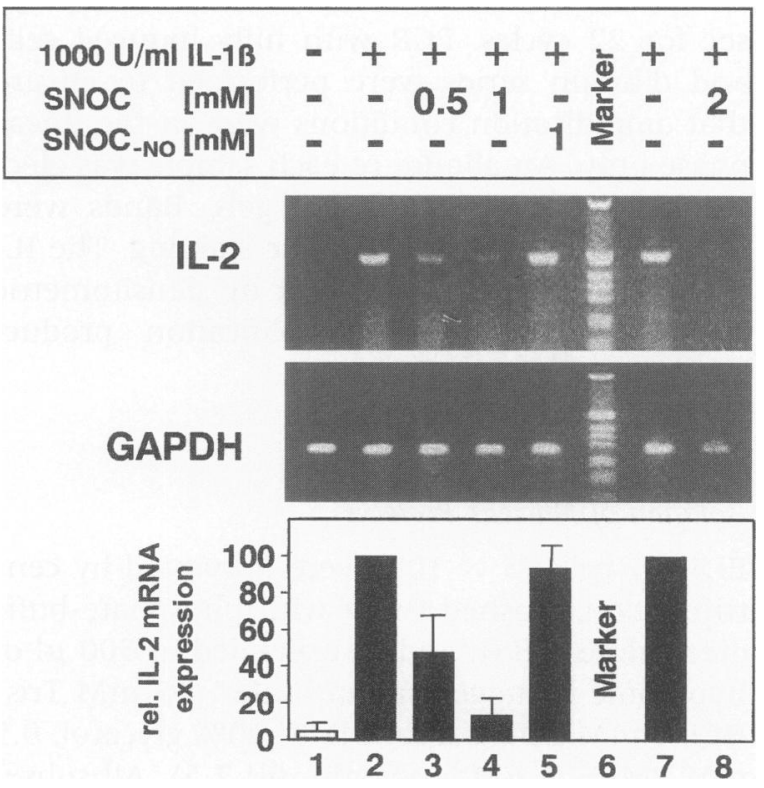

Fig. 2. Subtoxic concentrations of SNOC inhibit IL-1 $\beta$-dependent IL-2 mRNA expression in lymphocytes. EL4-6.1 cells were incubated for 3 $\mathrm{hr}$ without (lane 1) or with $1000 \mathrm{U} / \mathrm{ml} \mathrm{IL}-1 \beta$ in the absence (lanes 2,7 ) or presence of various concentrations of SNOC (lanes 3, 4, 8) or SNOC - NO (lane 5). Subsequently, total cellular RNA was isolated and IL-2- and GAPDH-specific RT-PCR was performed. IL-2 mRNA was quantitated in relation to GAPDH mRNA. Apoptosis-inducing high concentrations of SNOC reduced both IL-2 and GAPDH mRNA expression, whereas subtoxic concentrations of SNOC only decreased IL-2 mRNA in a concentration-dependent manner. Values are mean \pm SD of five independent experiments. 


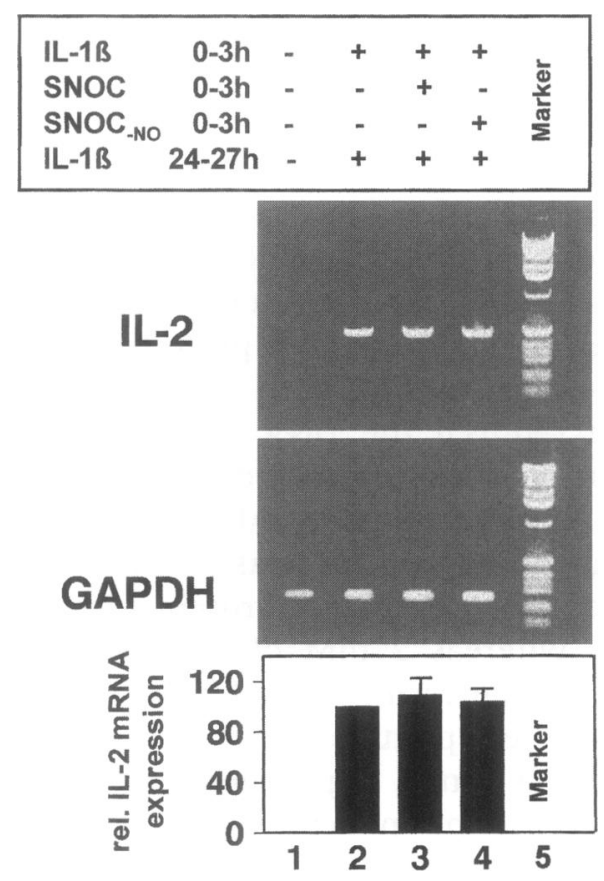

Fig. 3. SNOC-mediated inhibition of IL-2 mRNA expression is reversible. EL4-6.1 cells were incubated without (lane 1) or with $1000 \mathrm{U} / \mathrm{ml}$ $\mathrm{IL}-1 \beta$ in the absence (lane 2 ) or presence of $1 \mathrm{mM}$ of SNOC (lane 3) or SNOC - NO (lane 4). After $3 \mathrm{hr}$, cells were carefully washed and incubated for $24 \mathrm{hr}$ in fresh culture medium. Cells were then incubated again without (lane 1 ) or with IL-1 $\beta$ (lanes $2-4$ ) for $3 \mathrm{hr}$. IL-2 mRNA was quantitated in relation to GAPDH mRNA. Under these conditions, inhibition of IL-2 mRNA expression was fully reversible. Values are mean \pm SD of three independent experiments.
NO-Mediated Inhibition of IL-2 mRNA Is Reversible

To investigate whether the NO-mediated reduction of the IL-2 mRNA expression was reversible, cells activated with IL-1 $\beta$ were treated with 1 $\mathrm{mM}$ of SNOC or SNOC $-\mathrm{NO}$ for $3 \mathrm{hr}$ and washed and cultured in fresh culture medium for an additional $24 \mathrm{hr}$ in the absence of IL-1 $\beta$ or SNOC, respectively. Subsequently, cultures were incubated again with IL- $1 \beta$ for $3 \mathrm{hr}$. Figure 3 shows that IL- $1 \beta$-induced IL- 2 mRNA expression was not reduced in SNOC-pretreated cells as compared to sham-treated cells. These results show that NO-mediated inhibition of IL- $1 \beta$-dependent IL-2 mRNA expression is fully reversible within $24 \mathrm{hr}$ and is not due to toxicity.

NO Affects IL-1 $\beta$-Dependent IL-2 mRNA Expression Only during Induction Phase

To investigate whether SNOC inhibits IL-2 gene expression when given after or before the activation stimulus IL-1 $\beta$, EL4-6.1 cells were activated with IL-1 $\beta$ for 30 min prior to the subsequent addition of SNOC. Cells were then cultured for another $2.5 \mathrm{hr}$. Figure 4 shows that $1 \mathrm{mM}$ SNOC did not inhibit IL-2 mRNA expression when applied 30 min after IL- $1 \beta$. In contrast, preincubation of cells with $1 \mathrm{mM}$ SNOC for 30 min followed by addition of IL- $1 \beta$ for another $2.5 \mathrm{hr}$ resulted in a significant reduction in IL$1 \beta$-dependent IL-2 mRNA expression (Fig. 4, lane 7), whereas $\mathrm{SNOC}_{-\mathrm{NO}}$ had no effect. These results demonstrate that NO inhibits IL-l $\beta$-de-

\begin{tabular}{|c|c|c|c|c|c|c|c|}
\hline Preincubation with IL-1B & + & + & + & - & - & - & - \\
\hline SNOC [mM] & -0.5 & 1 & - & - & 0.5 & 1 & - $\quad \bar{\phi}$ \\
\hline $\mathrm{SNOC}_{-\mathrm{NO}}[\mathrm{mM}]$ & $-\quad-$ & - & 1 & - & - & - & 1 \\
\hline postincubation with IL-1B & - & - & - & + & + & + & + \\
\hline
\end{tabular}

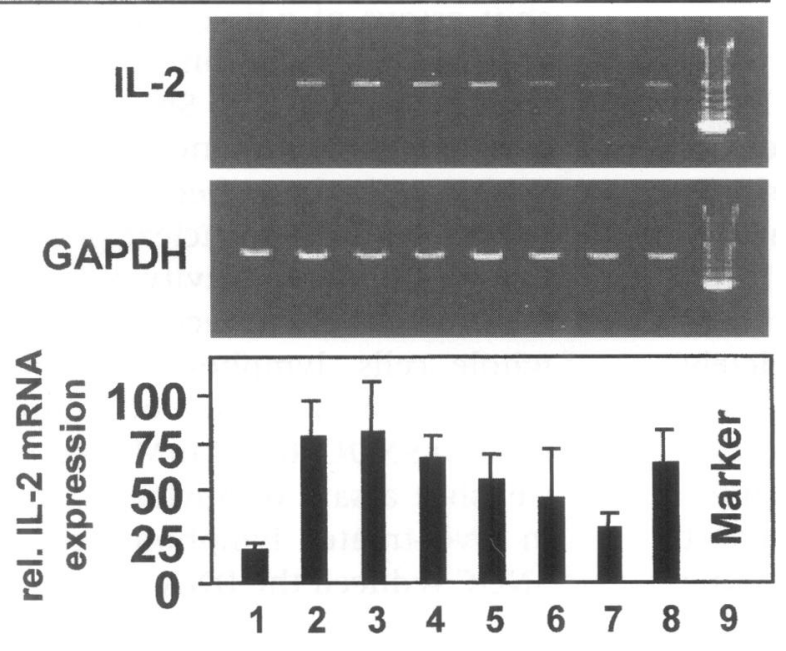

Fig. 4. SNOC inhibits IL-2 mRNA expression only during the induction phase. EL4-6.1 cells were incubated without (lane 1) or with $1000 \mathrm{U} / \mathrm{ml}$ IL- $1 \beta$ (lanes 2-8) for $3 \mathrm{hr}$. Cells were incubated with IL- $1 \beta 30 \mathrm{~min}$ prior to addition of 0.5 mM SNOC (lane 2), $1 \mathrm{mM}$ SNOC (lane 3) or $1 \mathrm{mM} \mathrm{SNOC}_{-\mathrm{NO}}$ (lane 4). Cells were also treated the other way round. After culture in the absence (lane 5) or presence of $0.5 \mathrm{mM}$ SNOC (lane 6), $1 \mathrm{mM}$ SNOC (lane 7), or $1 \mathrm{mM}$ SNOC_ 8 ) for $30 \mathrm{~min}$, cells were incubated with IL- $1 \beta$ for $3 \mathrm{hr}$. Results show that NO must be present during the induction phase to inhibit IL-2 mRNA expression. Values are mean $\pm \mathrm{SD}$ of three independent experiments. 


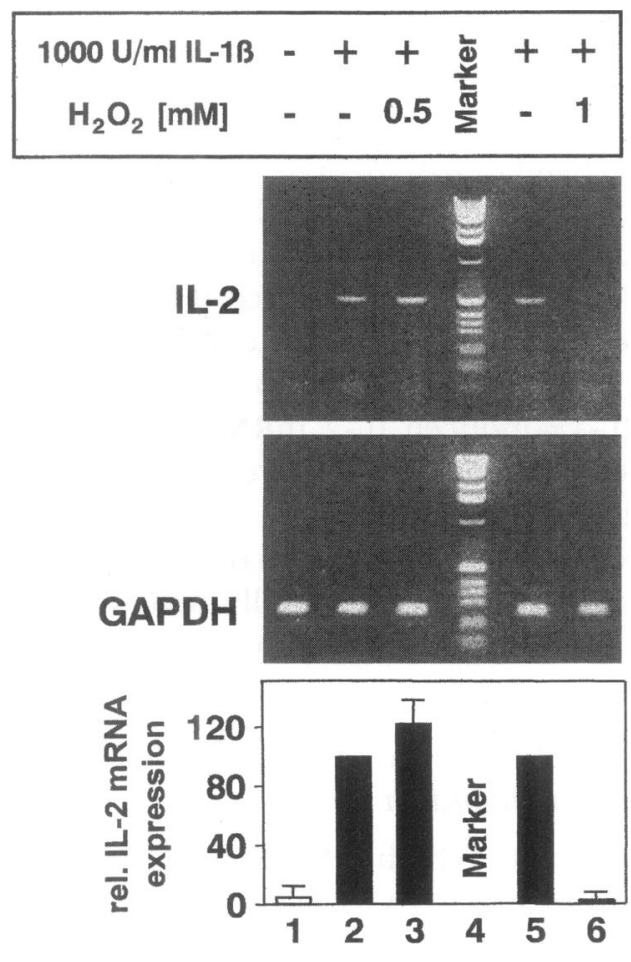

Fig. 5. Subtoxic concentrations of $\mathrm{H}_{2} \mathrm{O}_{2}$ augment IL-1 $\beta$-dependent IL-2 mRNA expression in lymphocytes. EL4-6.1 cells were incubated for $3 \mathrm{hr}$ without (lane 1) or with $1000 \mathrm{U} / \mathrm{ml} \mathrm{IL-1} \beta$ in the absence (lanes 2,5 ) or presence of 0.5 (lane 3) or 1 $\mathrm{mM}$ of $\mathrm{H}_{2} \mathrm{O}_{2}$ (lane 6). Total cellular RNA was isolated and IL-2- and GAPDH-specific RT-PCR performed. IL-2 mRNA was quantitated in relation to GAPDH mRNA. Apoptosis-inducing high concentrations of $\mathrm{H}_{2} \mathrm{O}_{2}$ reduced both IL-2 and GAPDH mRNA expression, whereas subtoxic concentrations of $\mathrm{H}_{2} \mathrm{O}_{2}$ slightly increased cellular IL-2 mRNA expression. Values are mean \pm SD of three independent experiments.

pendent IL-2 mRNA expression only during the induction phase.

\section{$\mathrm{H}_{2} \mathrm{O}_{2}$ Slightly Enhances $\mathrm{IL}-1 \beta$-dependent IL-2}

mRNA Expression

When EL4-6.1 cells were activated with IL- $1 \beta$ for $3 \mathrm{hr}$ in the presence of various concentrations of $\mathrm{H}_{2} \mathrm{O}_{2}$, results were different, as treatment of cells with $0.5 \mathrm{mM}$ of $\mathrm{H}_{2} \mathrm{O}_{2}$ led to a slight enhancement of IL-2 mRNA synthesis (Fig. 5). At $1 \mathrm{mM}$ of $\mathrm{H}_{2} \mathrm{O}_{2}$, where significant apoptosis occurs (see Fig. 1B), IL-2 mRNA expression was completely inhibited and GAPDH expression was reduced. These results clearly show that in viable cells, subtoxic nitrosative, in contrast to oxidative, stress inhibits IL-2 gene transcription. This effect is specific and is not due to loss of lymphocytic viability.

\section{NO Affects DNA Binding Activities of Spl and EGR-1}

The murine IL-2 promoter contains a ZIP site, which serves as a binding site for the two zinc finger proteins Spl and EGR-1 $(20,21)$. To investigate whether these zinc finger proteins represent possible molecular targets, we analyzed whether NO treatment affects the DNA binding activities of these proteins. Treatment of recombinant Spl with SNOC for $30 \mathrm{~min}$ indeed reduced the DNA binding activity of Spl in a concentration-dependent manner (Fig. 6A). Near complete inhibition of the DNA binding activity of $\mathrm{Spl}$ was found after treatment of the recombinant protein with $2 \mathrm{mM}$ of SNOC, whereas $2 \mathrm{mM}$ of $\mathrm{SNOC}_{-\mathrm{NO}}$ had no effect. Similar results were found using PAPA/ NO, another spontaneous but chemically unrelated NO donor. Experiments using the zinc finger transcription factor EGR-1 showed comparable results (not shown).

\section{NO Affects DNA Binding Activity of Nuclear Spl}

Next we investigated whether NO applied to the total nuclear protein extracts affects the DNA binding activity of endogenous Spl. To determine this, nuclear extracts from IL- $1 \beta$ activated EL4-6.1 lymphocytes were prepared. Gel shift assays with an oligonucleotide representing the ZIP site of the murine IL-2 promoter showed a single retarded band (Fig. 6B). This band seems to represent a single nuclear protein, as antibodies specific for Spl, but not for EGR-1, induced a supershift (not shown). This suggests that in IL- $1 \beta$-activated murine EL4-6.1 lymphocytes, Spl may play a dominant role as single transcription factor in IL$1 \beta$-dependent IL- 2 mRNA expression. We therefore focused on $\mathrm{Spl}$ to characterize the role of NO on transcription factor activity. Gel shift assays of whole nuclear extracts treated with SNOC for 30 min revealed that the DNA binding activity of $\mathrm{Spl}$ was inhibited in a concentration-dependent manner, whereas SNOC $_{- \text {NO }}$ had no effect (Fig. 6B). Thus, in the presence of other nuclear proteins, NO affects the DNA binding activity of Spl. To investigate whether NO also affects Spl binding activity in whole cells, lymphocytes were treated with IL- $1 \beta$ in the presence of subtoxic concentrations of SNOC (0.5-1 mM) and $\mathrm{H}_{2} \mathrm{O}_{2}(0.5 \mathrm{mM})$. Gel shift assays of nuclear extracts from these in vivo-treated lymphoma cells revealed that SNOC reduced the DNA binding activity of $\mathrm{Spl}$ (Fig. 6C), whereas neither SNOC $_{- \text {NO }}$ nor 0.5 


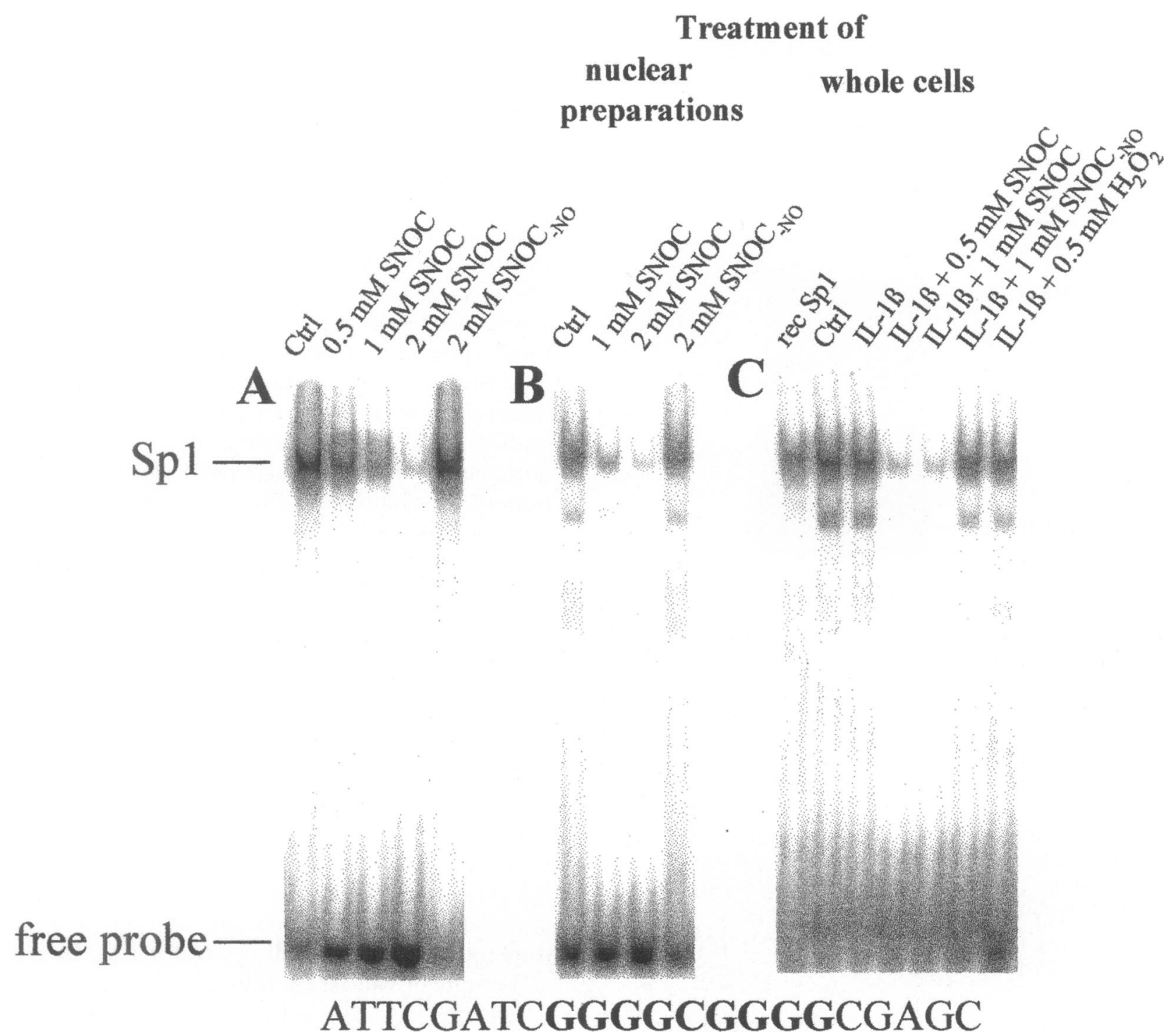

Fig. 6. SNOC inhibits DNA binding activity of zinc finger transcription factor Spl. Gel shift experiments were performed with $\mathrm{Spl}$-specific ${ }^{32} \mathrm{P}$ labeled oligonucleotide probes (sequence indicated below) and recombinant $\mathrm{Spl}(\mathrm{A})$ or nuclear extracts from EL4-6.1 cells (B, C). (A) Recombinant Spl was incubated in the absence (Ctrl) or presence of 0.5 $\mathrm{mM}, 1 \mathrm{mM}$, or $2 \mathrm{mM}$ of SNOC or $2 \mathrm{mM}$ of SNOC $_{- \text {NO }}$ for $30 \mathrm{~min}$ at room temperature. Subsequent electrophoretic mobility shift assays revealed that SNOC, in contrast to SNOC - NO decreased the Spl binding activity in a concentration-dependent manner. (B) Nuclear extracts of IL- $1 \beta$-treated EL46.1 lymphoma cells were treated without $(\mathrm{Ctrl})$ or

mM $\mathrm{H}_{2} \mathrm{O}_{2}$ showed any effect. This result demonstrates that NO affects the DNA binding activity of the zinc finger transcription factor $\mathrm{Spl}$ in whole cells and that the relatively long-living radical NO indeed can affect nuclear targets. with 1 or $2 \mathrm{mM}$ of SNOC or with $2 \mathrm{mM}$ of $\mathrm{SNOC}_{-\mathrm{NO}}$ for $30 \mathrm{~min}$ at room temperature. As with the recombinant Spl, SNOC, in contrast to SNOC $_{-\mathrm{NO}}$, inhibited the DNA binding activity of nuclear Spl. (C) EL4-6.1 lymphoma cells were incubated for $3 \mathrm{hr}$ without (Ctrl) or with $1000 \mathrm{U} / \mathrm{ml}$ IL- $1 \beta$ in the absence or presence of $0.5 \mathrm{mM}$ or 1 $\mathrm{mM}$ of SNOC, $1 \mathrm{mM}$ of $\mathrm{SNOC}_{-\mathrm{NO}}$, or $0.5 \mathrm{mM}$ of $\mathrm{H}_{2} \mathrm{O}_{2}$. Subsequently, nuclear extracts were prepared. SNOC $(0.5$ and $1 \mathrm{mM})$, in contrast to SNOC $_{-\mathrm{NO}}$ or $0.5 \mathrm{mM}$ of $\mathrm{H}_{2} \mathrm{O}_{2}$, greatly reduced the binding of nuclear Spl to its consensus oligonucleotide. Representative experiments are shown.

NO Does Not Affect DNA Binding Activity of NFAT

In addition to the ZIP site, a NFAT binding site located directly downstream of the ZIP site also plays an important role in maximal IL-2 promoter activity. To prove whether the effects of 


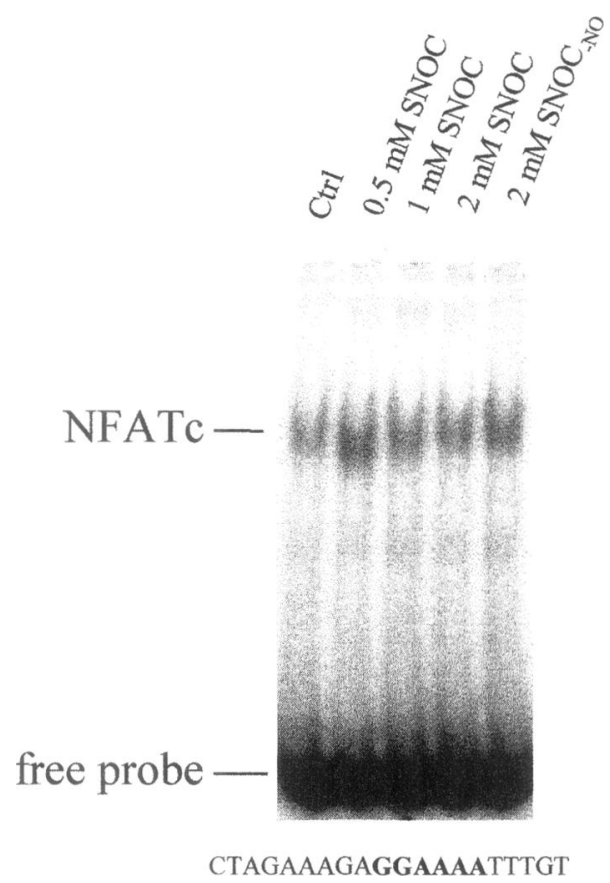

Fig. 7. SNOC does not affect DNA binding activity of transcription factor NFATc. Gel shift experiments were performed with recombinant NFATC and NFAT-specific ${ }^{32} \mathrm{P}$-labeled oligonucleotide probes (sequence indicated below). Recombinant NFATc was incubated in the absence (Ctrl) or presence of $0.5 \mathrm{mM}, 1 \mathrm{mM}$, or $2 \mathrm{mM}$ of SNOC or $2 \mathrm{mM}$ of $\mathrm{SNOC}_{-\mathrm{NO}}$ for $30 \mathrm{~min}$ at room temperature. Subsequent electrophoretic mobility shift assays revealed that neither SNOC nor SNOC - No decreased the DNA binding activity of NFATc. A representative experiment is shown.

NO were specific for zinc finger transcription factors, we investigated whether $\mathrm{NO}$ affects the DNA binding of recombinant NFATc, which lacks a zinc finger structure. Figure 7 shows that SNOC at concentrations of up to $2 \mathrm{mM}$ did not inhibit the binding of NFATc to its specific IL-2 promoter element. This result demonstrates that reactions of NO with transcription factor proteins involved in the regulation of the IL-2 promoter are selective.

\section{Discussion}

Recently, several reports have examined the inhibitory role of NO on IL-2 protein synthesis in T cells (12-16). Here we show that exogenously added NO inhibits IL-2 expression in lymphoma cells at the transcriptional level. Subtoxic concentrations of NO, in contrast to subtoxic concentrations of $\mathrm{H}_{2} \mathrm{O}_{2}$, decrease the IL- $1 \beta$-depen- dent expression of IL-2 mRNA in a reversible manner, which correlates with the inactivation of the DNA binding activity of the zinc finger transcription factor Spl.

The slowly NO-releasing NO donor SNAP (100 $\mu \mathrm{M})$ has been shown to inhibit IL-2 production in human or murine $\mathrm{T}$ cells or $\mathrm{T}$ cell lines activated with anti-CD3 monoclonal antibody (MAb) or with Con A by about $40-90 \%$ after 24-48 hr (13-16). Since pilot experiments had shown that IL-2 mRNA expression reached a maximal level at $3 \mathrm{hr}$ after addition of IL-1, we used SNOC as a physiological NO donor with a relatively short half-life. To determine the effects on IL-2 gene expression within this $3 \mathrm{hr}$ incubation period, we used 0.5-1 mM SNOC, concentrations that may appear to be supraphysiological. However, we recently found that both $2 \mathrm{mM}$ of SNOC and $2 \mathrm{mM}$ of the NO donor DETA/NO mediate comparable intracellular and intranuclear $\mathrm{Zn}^{2+}$ release in cells after $\mathrm{l}$ and $24 \mathrm{hr}$, respectively (23). DETA/NO generates NO for several hours in concentrations that are comparable to NO concentrations measured in cell monolayers expressing the inducible NO synthase (for discussion see ref. 23). In addition, in a cell monolayer and in vivo in infiltrated inflammatory sites, NO synthesis will occur in the immediate vicinity of cellular targets. In contrast, NO generated by chemical NO donors will decay in the entire volume of the cell culture medium, thus most of the NO will be oxidized to nitrite and nitrate or will escape into the gas phase prior to reaching the target cells. Furthermore, in vivo NO produced by the inducible NO synthase may exert effects over periods of days or weeks. This may explain why relatively high NO donor concentrations (usually in the low millimolar range) must be used to induce nitrosative stress in cells in vitro. Additionally, the exact fate and NOreleasing rates of $S$-nitrosothiols in cells are unknown. Moreover, further culture of treated cells after removal of NO donors showed complete reversibility as well as full growth competence, demonstrating nontoxic conditions.

Conflicting results in regulation of IL-2 synthesis by $\mathrm{T}$ cells have been reported for $\mathrm{NO}$ generated by an NO donor versus NO synthesized by cells. In contrast to exogenously added NO, in a $\mathrm{T}$ cellmacrophage coculture system IL-2 secretion was not found to be increased after addition of a NO synthase inhibitor to block macrophage-secreted NO (12). However, in these experiments, IL-2 synthesis was already maximal in the isolated lymph 
node cells and under these conditions, NO-mediated inhibition of IL-2 will not occur.

It appears that the transcription factor $\mathrm{Spl}$ is susceptible to redox changes, as in vitro treatment with very high concentrations of $\mathrm{H}_{2} \mathrm{O}_{2}$ (10-20 mM) has been reported to inhibit Spl DNA binding activity $(31,32)$. By using the $\mathrm{Zn}^{2+}$ complexing protein metallothionein as a model for zinc sulfur complex-containing proteins, we previously demonstrated that NO will nitrosylate cysteine $\mathrm{SH}$-groups and thus induce metal release from metallothionein (22). We show here for the first time that NO inhibits the DNA binding activity of a zinc finger transcription factor in cells and we propose that $S$-nitrosylation of cysteine $\mathrm{SH}$-groups mediates $\mathrm{Zn}^{2+}$ release from $\mathrm{Spl}$, resulting in a conformational change in the $\mathrm{Spl}$ zinc finger binding domain. This hypothesis is further supported by our previous finding that in living cells, NO will rapidly increase the pool of labile $\mathrm{Zn}^{2+}$, especially in nuclei (23). Furthermore, we observed a substantial difference between nitrosative and oxidative stress. The finding that NO affects IL-2 mRNA expression only when cells are treated with SNOC prior to or simultaneously with IL- $1 \beta$ activation but not when treated $30 \mathrm{~min}$ after the IL- $1 \beta$ stimulus demonstrates that NO is active during the induction phase of transcription only. Our results indicate that once the transcription factors have bound, NO will not interfere with DNA binding and transcription, which suggests that in the DNA-protein complex, the zinc finger structure is stabilized and/or inaccessible for NO.

The ZIP site of the IL-2 promoter is a binding site for the zinc finger proteins $\mathrm{Spl}$ and EGR-1. Following stimulation of human lymphocytes by phorbol 12-myristate 13-acetate (PMA), gene reporter assays with the human IL-2 promoter construct including a ZIP site revealed a synergistic interaction between EGR-1 and NFATc $(20,21)$. Recombinant EGR-1 binds weakly to the ZIP site of the murine IL-2 promoter (not shown). However, it appears likely that this element also interacts with the adjacent NFAT binding site to regulate IL-2 gene expression.

In addition to its demonstrated effects on Spl and EGR-1, NO will act on other transcription factors as well. NO has been shown to inhibit the activation of the transcription factor NF- $\kappa \mathrm{B}$ via induction and inhibition of proteolytic degradation of its inhibitor $\mathrm{I} \kappa \mathrm{B} \alpha(33)$ and to inhibit the DNA binding activity of NF- $\kappa \mathrm{B}(34,35)$ as well as that of AP-1 (36). Because the IL-2 promoter contains binding sites for these two transcription factors (17), NO- mediated immunosuppression, as demonstrated here by the inhibition of IL-2 gene expression, likely represents a concerted action of NO on all four transcription factors. However, the DNA binding activity of recombinant NFATc was not found to be affected by NO, probably because of the lack of cysteine residues essential for DNA binding (37). But through interactions with the neighboring ZIP site, onset of IL-2 gene expression might be impaired, especially with the physiological stimulus IL- $1 \beta$, which is relatively weak compared to ionomycin and/or PMA, which are usually applied in reporter gene assays.

In conclusion, inhibition of the DNA binding activities of transcription factors such as the zinc finger proteins Spl and EGR-1 appears to be a molecular mechanism for the inhibition of IL-2 gene expression by nitrosative stress and may at least in part explain the immunosuppressive effects of NO. Understanding the molecular events at work in NO-mediated immunosuppression will help us to exploit this naturally occuring mechanism to achieve suppression of unwanted immune reactions.

\section{Acknowledgments}

We thank Dr. V. Burckhardt (Diabetes Research Center at the Heinrich-Heine University of Düsseldorf) for supplying EL4-6.1 mouse lymphoma cells, Dr. C. Esser (Medical Institute for Environmental Hygiene, Düsseldorf) for supplying mouse IL-2 primer, O. Grapenthin (Institute of Pharmaceutical Chemistry, Heinrich-Heine University of Düsseldorf) for providing PAPA/NO, and $M$. Turken for the photographic work. This work was supported by grants from the Deutsche Forschungsgemeinschaft ( $\mathrm{Kr} 1443 / 3-1$ and 3-2 to K.D.K).

\section{References}

1. Nathan C. (1992) Nitric oxide as a secretory product of mammalian cells. FASEB J. 6: 3051-3064.

2. Kröncke KD, Fehsel K, Kolb-Bachofen V. (1995) Inducible nitric oxide synthase and its product nitric oxide, a small molecule with complex biological activities. Biol. Chem. 376: 327-343.

3. Kolb H, Kolb-Bachofen V. (1992) Nitric oxide: a pathogenic factor in autoimmunity. Immunol. Today 13: 157-160.

4. Bogdan C. (1998) The multiplex function of nitric oxide in (auto)immunity. J. Exp. Med. 187: 1361-1365.

5. Kröncke KD, Fehsel K, Kolb-Bachofen V. (1998) Inducible nitric oxide synthase in human diseases. Clin. Exp. Immunol. 113: 147-156. 
6. Wink DA, Mitchel JB. (1998) Chemical biology of nitric oxide: insights into regulatory, cytotoxic, and cytoprotective mechanisms of nitric oxide. Free Radic. Biol. Med. 25: 434-456.

7. Hoffman RA, Langrehr JM, Billiar TR, Curran RD, Simmons RL. (1990) Alloantigen-induced activation of rat splenocytes is regulated by the oxidative metabolism of L-arginine. J. Immunol. 145: 2220-2226.

8. Mills CD. (1991) Molecular basis of "suppressor" macrophages. Arginine metabolism via the nitric oxide synthetase pathway. J. Immunol. 146: 2719-2723.

9. Al-Ramadi BK, Meissler JJ, Huang D, Eisenstein TK. (1992) Immunosuppression induced by nitric oxide and ist inhibition by interleukin-4. Eur. J. Immunol. 22: 2249-2254.

10. Sternberg J, McGuigan F. (1992) Nitric oxide mediates suppression of $\mathrm{T}$ cell responses in murine Trypanosoma brucei infection. Eur. J. Immunol. 22: 2741-2744.

11. Kolb H, Kolb-Bachofen V. (1998) Nitric oxide in autoimmune disease: cytotoxic or regulatory mediator? Immunol. Today 19: 556-561.

12. Marcinkiewicz J, Grabowska A, Chain BM. (1996) Is there a role for nitric oxide in regulation of $\mathrm{T}$ cell secretion of IL-2? J. Immunol. 156: 4617-4621.

13. Taylor-Robinson AW. (1997) Inhibition of IL-2 production by nitric oxide: a novel self-regulatory mechanism for Thl cell proliferation. Immunol. Cell Biol. 75: 167-175.

14. Chang RH, Lin Feng MH, Liu WH, Lai MZ. (1997) Nitric oxide increases interleukin-4 expression in T lymphocytes. Immunology 90: 364-369.

15. Bauer H, Jung T, Tsikas D, Stichtenoth DO, Frölich JC, Neumann C. (1997) Nitric oxide inhibits the secretion of T-helper 1-and T-helper 2-associated cytokines in activated human $\mathrm{T}$ cells. Immunology 90: 205-211.

16. van der Veen RC, Dietlin TA, Pen L, Gray JD. (1999) Nitric oxide inhibits the proliferation of T-helper 1 and 2 lymphocytes without reduction in cytokine secretion. Cell. Immunol. 193: 194-201.

17. Serfling E, Avots A, Neumann M. (1995) The architecture of the interleukin-2 promoter: a reflection of T lymphocyte activation. Biochim. Biophys. Acta 1263: 181-200.

18. Kadonaga JT, Carner KR, Masiarz FR, Tjian R. (1987) Isolation of cDNA encoding transcription factor Spl and functional analysis of the DNA binding domain. Cell 51: 1079-1090.

19. Klug A, Schwabe JWR. (1995) Zinc fingers. FASEB J. 9: 597-604.

20. Skerka C, Decker EL, Zipfel PF. (1995) A regulatory element in the human interleukin 2 gene promoter is a binding site for the zinc finger proteins $\mathrm{Spl}$ and EGR-1. J. Biol. Chem. 270: 22500-22506.

21. Decker EL, Skerka C, Zipfel PF. (1998) The early growth response protein (EGR-1) regulates interleukin-2 transcription by synergistic interaction with the nuclear factor of activated T cells. J. Biol. Chem. 273: 26923-26930.
22. Kröncke $\mathrm{KD}$, Fehsel K, Schmidt T, et al. (1994) Nitric oxide destroys zinc-sulfur clusters inducing zinc release from metallthionein and inhibition of the zinc finger-type yeas transcription factor LAC9. Biochem. Biophys. Res. Commun. 200: 1105-1110.

23. Berendji D, Kolb-Bachofen V, Meyer KL, et al. (1997) Nitric oxide mediates intracytoplasmic and intranuclear zinc release. FEBS Lett. 405: 37-41.

24. Kröncke KD, Carlberg C. (2000) Inactivation of zinc finger transcription factors provides a mechanism for a gene regulatory role of nitric oxide. $F A S E B J$. In press.

25. Kröncke KD, Kolb-Bachofen V. (1996) Methods for the detection of nitric oxide interaction with zinc finger proteins. Methods Enzymol. 269: 279-284.

26. Chomczynski P, Sacchi N. (1987) Single-step method of RNA isolation by acid guanidinium thiocyanate-phenol-chloroform extraction. Anal. Biochem. 162: 156-159.

27. Gubler W, Hoffman B. (1983) A simple and very efficient method for generating cDNA libraries. Gene 25: 263-269.

28. Kashima N, Nishi-Takaoka C, Fujita T, Yamada G, Hamuro J, Taniguchi T. (1985) Unique structure of murine interleukin-2 as deduced from cloned cDNAs. Nature 313: 402-404.

29. Lowry OH, Rosebrough NJ, Farr AL, Randall JR. (1951) Protein measurement with the foline phenol reagent. J. Biol. Chem. 193: 265-275.

30. Lowenthal JW, Cerottini JC, MacDonald HR. (1986) Interleukin 1-dependent induction of both interleukin 2 secretion and interleukin 2 receptor expression by lymphoma cells. J. Immunol. 137: 1226-1231.

31. Knoepfel L, Steinkühler C, Carrì MT, Rotilio G. (1994) Role of zinc-coordination and of the glutathione redox couple in the redox susceptibility of human transcription factor Spl. Biochem. Biophys. Res. Commun. 201: 871-877.

32. Ammendola $R$, Mesuraca $M$, Russo $T$, Cimino $F$. (1994) The DNA-binding of Spl is affected by redox changes. Eur. J. Biochem. 225: 483-489.

33. Peng HB, Libby $P$, Liao JK. (1995) Induction and stabilization of $I \kappa B \alpha$ by nitric oxide mediates inhibition of NF-кB. J. Biol. Chem. 270: 14214-14219.

34. Matthews JR, Botting $\mathrm{CH}$, Panico M, Morris $\mathrm{HR}$, Hay RT. (1996) Inhibition of NF- $\kappa B$ DNA binding by nitric oxide. Nucl. Acids Res. 24: 2236-2242.

35. Moormann AM, Koenig RJ, Meshnick SR. (1996) Effects of hydrogen peroxide, nitric oxide and antioxidants on NF- $\mathrm{BB}$. Redox Rep. 2: 249-256.

36. Tabuchi A, Sano K, Oh E, Tsuchiya T, Tsuda $M$. (1994) Modulation of Ap-l activity by nitric oxide (NO) in vitro: NO-mediated modulation of AP-1. FEBS Lett. 351: 123-127.

37. Chen L, Glover JNM, Hogan PG, Rao A, Harrison SC. (1998) Structure of the DNA-binding domains from NFAT, Fos and Jun bound specifically to DNA. Nature 392: 42-48. 